\title{
Association of a Serum Opacity Reaction with Serological Type in Streptococcus pyogenes
}

\author{
BY H. GOODER \\ Streptococcus Reference Laboratory, Central Public Health Laboratory, \\ Colindale, London, N.W. 9
}

(Received 28 September 1960)

\section{SUMMARY}

Krumwiede(1954) reported that some group A streptococci formed a lipoproteinase which was capable of producing opalescence in horse serum. A survey of a large number of strains of group A streptococci has shown that those strains which carry an easily identifiable $\mathbf{M}$ antigen rarely produce the serum opalescence reaction, except for Types 2 and 9 . On the other hand those types that elaborate $M$ antigen poorly or not at all are usually good producers of the serum opacity reaction.

\section{INTRODUCTION}

In 1954 Krumwiede reported that some group A streptococci formed a lipoproteinase which produced opalescence in serum. Ward \& Rudd (1938) had noted that the production of similar opalescence in serum broth was confined to a few of the Lancefield types of group A streptococci, although they tested only one strain of each type. The association of serological types of group A Streptococcus pyogenes with the production of particular enzyme systems has been the subject of numerous reports. Crowley $(1944,1954)$ noted this effect with respect to both hyaluronidase and amylase production. Robinson, Blinn \& Frank (1952) and Williams (1954) reported similarly with glucuronidase and Lazarides \& Bernheimer (1957) with diphosphopyridine nucleotidase. This paper reports a comparison of the type antigens and ability to produce an opalescence in serum broth of a large number of strains.

\section{METHODS}

Organisms. A collection of 732 strains of group A streptococci were examined; of these 344 were obtained from lyophilized stocks held in the Streptococcus Reference Laboratory. These strains, collected during the last 20 years or more from clinical material, included the original Griffith type strains. The remaining strains were those submitted for routine type identification during a period of about 6 weeks. All the latter strains were grouped and typed at the time of testing for the serum opacity reaction, while only a selected number of the stock strains were retested for type antigens.

Media. Serum broth consisting of one part Hartley broth (pancreatic digest of beef) and three parts horse serum, sterilized by filtration, was used for the demonstration of the serum opacity reaction; final $\mathrm{pH} 7 \cdot 5$ by glass electrode. Serum from normal horses was obtained from the Medical Research Council Serum Laboratories, Carshalton. 
Proteinase was determined by the milk thioglycollate method of Elliott \& Dole (1947).

Lipoproteinase. Urea extraction of the organisms and the demonstration in the extract of lipoproteinase activity by paper electrophoresis were carried out by the method reported by Krumwiede (1954).

Hyaluronidase. Two hyaluronidase preparations were used: a culture fluid from a hyaluronidase-producing group A streptococcus; a bovine testicular extract. These preparations were checked for activity by the method of di Ferrante (1956).

Serological grouping and typing of the organisms were done by the methods described by Williams (1958).

Serum opalescence. The ability of each organism to produce a serum opalescence was determined as follows. All strains were grown overnight at $37^{\circ}$ in Todd-Hewitt broth to a final turbidity corresponding to about $10^{8}$ chains $/ \mathrm{ml}$. One loopful $(0.01 \mathrm{ml}$.) of the culture was transferred to $3 \mathrm{ml}$. of the serum broth which was then incubated for $18-24 \mathrm{hr}$. at $37^{\circ}$. At this time the opalescence of the medium was noted and the growth tested for purity and viability by plating one loopful on a blood agar plate. No quantitative assessment of the opalescence was attempted; the results were scored as positive or negative. Different observers were responsible for the results reported for the stock and laboratory groups of strains respectively.

The observed reaction was the production of an opalescence (or increase in opacity) in the serum broth used. This opalescence probably occurs because certain serum components are rendered insoluble. The lipoproteinase described by Krumwiede was a specific enzyme attacking the $\alpha_{1}$ lipoprotein of horse serum. The observable action of the lipoproteinase on horse serum is the production of a similar opalescence, but since many other factors might also produce this effect we have preferred the term serum opacity reaction, although we assume that the observed reaction is probably due to the lipoproteinase.

The results were not obscured by turbidity due to the growth of the streptococci, possibly because of the small difference between the refractive indices of the bacteria and of a medium containing $75 \%(\mathrm{v} / \mathrm{v})$ horse serum. Wichelhausen, Clark, Griffing \& Robinson (1958) showed that it was possible to have $10^{7}-10^{8}$ viable bacteria present in a $25 \%(v / v)$ albumin solution without any visible turbidity.

\section{RESULTS}

The top half of Table 1 records the serum opacity reaction of stock and routine strains of various types. At the time the work was performed, the laboratory had available anti-M precipitin typing sera against streptococci of Types $1,2,3,5,6,9$, $12,14,15,17,18,19,23,24,26,29,30,31,33,36,37,39$, and 43 . The lower half shows the results obtained with stock strains of other known types for which no anti-M sera were available. The strains had been assigned to these types at some time in the past on the basis of an $\mathbf{M}$ antigen. They are, however, 'difficult' types with which to prepare good anti-M precipitin sera. Table 2 gives the results found with strains identified by agglutination patterns due to the $\mathbf{T}$ or $\mathbf{R}$ antigens. The results are summarized (Table 3 ) in three categories: the types that produce easily demonstrable $M$ antigens, the types in which the $M$ antigen has been difficult to demonstrate, and finally those types that can at present be identified only by agglutination pattern. 
Table 1. Serum opacity reaction of 508 strains of Streptococcus pyogenes typed by $M$ precipitin tests

The top half of the table records the reactions obtained with strains for which good anti-M precipitin sera were available; the lower half includes strains for which $M$ precipitin sera are difficult to prepare.

\begin{tabular}{|c|c|c|c|c|c|c|}
\hline \multirow{2}{*}{$\begin{array}{l}\text { Serological } \\
\text { type }\end{array}$} & \multicolumn{2}{|c|}{ Stock strains } & \multicolumn{2}{|c|}{ Routine strains } & \multicolumn{2}{|c|}{ Total } \\
\hline & Positive & Negative & Positive & Negative & Positive & Negative \\
\hline 1 & $\mathbf{0}$ & 18 & 0 & 37 & $\mathbf{0}$ & 55 \\
\hline 2 & 10 & 1 & 19 & 0 & 29 & 1 \\
\hline 3 & 0 & 25 & 0 & 12 & $\mathbf{0}$ & 37 \\
\hline 5 & 1 & 18 & 2 & 10 & 3 & 28 \\
\hline 6 & $\mathbf{0}$ & 14 & $\mathbf{0}$ & 9 & $\mathbf{0}$ & 23 \\
\hline $\mathbf{9}$ & 14 & 0 & 10 & 0 & 24 & $\mathbf{0}$ \\
\hline 10 & 0 & 4 & - & - & $\mathbf{0}$ & 4 \\
\hline 12 & 2 & 14 & 6 & 37 & 8 & 51 \\
\hline 14 & o & 8 & $\ldots$ & $\ldots$ & 0 & 8 \\
\hline 15 & 1 & 9 & - & - & 1 & 9 \\
\hline 17 & 0 & 13 & - & - & 0 & 13 \\
\hline 18 & 0 & 8 & $\mathbf{0}$ & $\mathbf{5 0}$ & $\mathbf{0}$ & 58 \\
\hline 19 & $\mathbf{0}$ & 8 & $\mathbf{0}$ & 8 & 0 & 16 \\
\hline 23 & 1 & 0 & - & - & 1 & 0 \\
\hline 24 & 1 & 10 & - & - & 1 & 10 \\
\hline 26 & 0 & 6 & 1 & 0 & 1 & 6 \\
\hline 29 & 1 & 7 & - & - & 1 & 7 \\
\hline 30 & 0 & 4 & - & - & 0 & 4 \\
\hline 31 & 0 & 4 & - & - & 0 & 4 \\
\hline 33 & 0 & 6 & - & - & 0 & 6 \\
\hline 36 & 0 & 7 & - & - & 0 & 7 \\
\hline 37 & 0 & 1 & - & - & 0 & 1 \\
\hline 39 & 0 & 4 & - & - & 0 & 4 \\
\hline \multirow[t]{2}{*}{43} & 1 & 10 & - & - & 1 & 10 \\
\hline & 32 & 199 & 38 & 163 & 70 & 362 \\
\hline 8 & 10 & 0 & - & - & 10 & 0 \\
\hline 11 & 11 & 2 & - & - & 11 & 2 \\
\hline 13 & 10 & 0 & - & - & 10 & 0 \\
\hline 25 & 10 & o & - & - & 10 & 0 \\
\hline 27 & 2 & 7 & - & - & 2 & 7 \\
\hline 32 & 0 & 3 & - & - & 0 & $\mathbf{3}$ \\
\hline 34 & 0 & 3 & - & - & 0 & $\mathbf{3}$ \\
\hline 35 & 1 & 2 & - & - & 1 & 2 \\
\hline 38 & 0 & 4 & - & - & 0 & 4 \\
\hline 40 & 0 & 3 & - & - & 0 & 3 \\
\hline 41 & 0 & 5 & - & - & 0 & 5 \\
\hline \multirow[t]{2}{*}{42} & 1 & 2 & - & - & 1 & 2 \\
\hline & 45 & 31 & & & 45 & 31 \\
\hline
\end{tabular}

It has long been known (Todd \& Lancefield, 1928) that the colonial differences apparent in many cultures of group A streptococci are sometimes related to the presence or absence of the $M$ antigen. It was of interest to determine whether, when these variant colonies were picked and grown separately, the negative association of serum opalescence and $\mathbf{M}$ antigen would still be found. Two strains were studied in this manner. One, on isolation, had the typing 5/27/44 but gave no precipitin reaction with Type 5 antiserum. It was serum-opalescence positive. 
Table 2. Serum opacity reaction of 224 strains of Streptococcus pyogenes typed by $T$ agglutination pattern

\begin{tabular}{|c|c|c|c|c|c|c|}
\hline \multirow[b]{2}{*}{ Serological type } & \multicolumn{2}{|c|}{ Stock strains } & \multicolumn{2}{|c|}{ Routine strains } & \multicolumn{2}{|c|}{ Total } \\
\hline & Positive & Negative & Positive & Negative & Positive & Negative \\
\hline 4 & 24 & 1 & 47 & 2 & 71 & $\mathbf{3}$ \\
\hline 28 & 11 & 1 & $\mathbf{3 7}$ & 3 & 48 & 4 \\
\hline 1 & - & - & $\mathbf{0}$ & 2 & $\mathbf{0}$ & 2 \\
\hline 6 & - & 一 & $\mathbf{0}$ & 1 & $\mathbf{0}$ & 1 \\
\hline 9 & - & - & 0 & 1 & 0 & 1 \\
\hline 14 & - & 一 & 2 & 1 & 2 & 1 \\
\hline 22 & 一 & - & 27 & $\mathbf{0}$ & 27 & $\mathbf{0}$ \\
\hline $8 / 25$ & - & - & 17 & $\mathbf{5}$ & 17 & 5 \\
\hline $5 / 11 / 27 / 44 *$ & - & - & 24 & 1 & 24 & 1 \\
\hline $\int 8 /$ Imp.19 & - & - & 11 & $\mathbf{0}$ & 11 & $\mathbf{0}$ \\
\hline$\{\operatorname{Imp} .19$ & - & - & 2 & $\mathbf{0}$ & 2 & $\mathbf{0}$ \\
\hline 3/13/B3264 & - & - & 4 & $\mathbf{0}$ & 4 & $\mathbf{0}$ \\
\hline Total & 35 & 2 & 171 & 16 & 206 & 18 \\
\hline
\end{tabular}

* Recent work in our laboratory has shown that many strains of this typing pattern are in fact Type 11, for which an anti-M precipitin serum is now available, and some of the others have the agglutination pattern 5/27/44, which is characteristic of strains having the Type $5 \mathrm{M}$ antigen.

$-=$ not tested.

A variant obtained from a single colony on subculture gave a Type $5 \mathrm{M}$ precipitin reaction and did not produce an opalescence in serum broth. Similarly, a strain with the agglutination reaction 12 but not carrying Type $12 \mathrm{M}$ antigen gave rise to a variant which did carry this antigen. The culture with $M$ antigen did not give the serum reaction while the culture with no demonstrable $M$ antigen produced the opalescence. That cultures sometimes consist of such mixtures giving serum opacity reactions around single colonies on serum agar plates had been noticed in the past (W. R. Maxted, personal communication).

Table 3. Relationship of serum opacity reaction to serological type in Streptococcus pyogenes

\begin{tabular}{|c|c|c|c|c|}
\hline & \multirow{2}{*}{$\begin{array}{c}\text { No. } \\
\text { tested }\end{array}$} & \multicolumn{2}{|c|}{ Serum opalescence reaction } & \multirow{2}{*}{$\begin{array}{c}\text { Percentage } \\
\text { positive }\end{array}$} \\
\hline & & Positive & Negative & \\
\hline Good M antigen types* & 439 & 72 & $\mathbf{3 6 7}$ & $16 \cdot 4$ \\
\hline $\begin{array}{l}\text { Types from which } M \text { antigen } \\
\text { can be extracted with difficulty } \\
\text { or not at all } \dagger\end{array}$ & 229 & 191 & 38 & $83 \cdot 4$ \\
\hline $\begin{array}{l}\text { Types recognized only by } \mathbf{T} \\
\text { agglutination pattern }\end{array}$ & 64 & $\mathbf{5 8}$ & 6 & $90 \cdot 6$ \\
\hline
\end{tabular}

No association could be demonstrated between the serum opacity reaction and the production by the organisms of hyaluronidase or proteinase. Hyaluronidase preparations or crystalline proteinase had themselves no visible action on horse serum during $\frac{1}{2} \mathrm{hr}$. incubation at $37^{\circ}$. Extracts of streptococci, obtained from cultures known to produce a serum opacity reaction, by the use of urea (Krumwiede, 1954), 
produced a pronounced opalescence when mixed with horse serum for $\frac{1}{2} \mathrm{hr}$. at $37^{\circ}$. Similarly, extracts prepared by lysis of washed streptococci with the phage-associated enzyme (Maxted, 1957) also produced opacity in horse serum even though they frequently did not possess proteinase or hyaluronidase activity.

The association of the serum opacity reaction with the lack of demonstrable $M$ antigen did not appear to be due to alteration of the antigen since active extracts did not destroy isolated $M$ antigen nor did the $M$ antigen disappear from the surface of organisms when they were suspended in such extracts.

\section{DISCUSSION}

The results show that those strains of Streptococcus pyogenes which carry $\mathbf{M}$ antigen rarely produce the serum opacity reaction with the exceptions of Types 2 and 9. In contrast, serotypes usually producing the serum opacity reaction are those which elaborate $\mathbf{M}$ antigen poorly or not at all and are identified by their other surface antigens, either $\mathbf{T}$ or $\mathbf{R}$. This relationship of the serum opacity reaction to the possession of $M$ antigen is readily apparent from the results presented in Table 3. The isolation of $M$ positive and $M$ negative variants from both a Type 5 and a Type 12 culture and their resultant serum opacity reactions further demonstrated this relation. No association could be demonstrated between the serum reaction, streptococcal proteinase or hyaluronidase. These enzymes may reasonably have been expected to have an effect on the loss of $M$ antigen from the surface had they occurred along with the lipoproteinase. Similarly, the lipoproteinase had no detectable activity on $\mathbf{M}$ antigen suggesting that the correlation is unlikely to be due to a direct interaction between this antigen and the factors responsible for the serum opacity reaction.

Krumwiede (1954) suggested that the serum opacity reaction was not due solely to a lipoproteinase but was more likely based on the interaction of a number of enzyme systems and accessory factors. She found no direct correlation between the degree of opalescence and the splitting of the lipoprotein. When, however, we tested active extracts obtained from four strains producing serum opalescence for the presence of factors capable of splitting horse serum lipoprotein, with each one such a splitting was found. Thus our studies may be interpreted as showing an inverse relationship between the presence of $M$ antigen and the production of a specific enzyme.

Previous reports have also suggested an inverse relationship between the production of $M$ antigen and particular enzymes. Williams (1954) noted that less than $1 \%$ of 324 M precipitin positive strains but approximately $17 \%$ of 371 strains identified by $\mathbf{T}$ agglutination pattern (or $R$ antigen in Type 28 ) produced glucuronidase. Similarly, Crowley (1954) observed that streptococcal amylase was frequently elaborated by strains of Streptococcus pyogenes of Types 2 and 4 , while only occasionally was it a product of other serological types. She found that while only $20 \%$ of 121 strains typed by $M$ precipitin reaction were amylolytic $62 \%$ of 70 strains typed by agglutination pattern produced the amylase. Similarly, strong hyaluronidase producing strains are found more frequently among serological types such as Types 4 and 22 in which it is frequently difficult to demonstrate the presence of the $\mathbf{M}$ precipitating antigen. The present results on lipoproteinase support the impression, 
held by many investigators, that strains carrying serologically demonstrable $\mathbf{M}$ antigen have a more limited array of certain enzymic capacities than those strains against which, in our laboratory, it is difficult consistently to prepare satisfactory antisera to their type specific $M$ antigen.

\section{REFERENCES}

Crowley, N. (1944). Hyaluronidase production by haemolytic streptococci of human origin. J. Path. Bact. 56, 27.

Crowley, N. (1954). On amylolytic strains of Streptococcus pyogenes. J. gen. Microbiol. $10,411$.

Di Ferrante, N. (1956). Turbidimetric measurement of acid mucopolysaccharides and hyaluronidase activity. J. biol. Chem. 220, 303.

Elisotr, S. D. \& Dole, V. P. (1947). An inactive precursor of streptococcal proteinase. J. exp. Med. 85, 305.

KrumwiEde, E. (1954). Studies on a lipoproteinase of group A streptococci. J. exp. Med. $100,629$.

Lazarides, P. D. \& Bernheimer, A. W. (1957). Association of production of diphosphopyridine nucleotidase with serological type of group A streptococcus. J. Bact. 74, 412.

MAXTED, W. R. (1957). The active agent in nascent phage lysis of streptococci. J. gen. Microbiol. 16, 584.

Robinson, J. J., Blinn, C. W. \& Frank, P. F. (1952). Glucuronidase production by Streptococcus pyogenes. J. Bact. 64, 719.

Todd, E. W. \& LANCEFIELd, R. C. (1928). Variants of haemolytic streptococci: their relation to type specific substance, virulence and toxin. J. exp. Med. 48, 751 .

WARD, H. K. \& RUDD, G. V. (1938). Studies on haemolytic streptococci from human sources. 1. The cultural characteristics of potentially virulent strains. Aust. J. exp. Biol. med. Sci. 16, 181.

Wichelhausen, R. H., Clark, H. W., Griffing, V. F. \& Robinson, L. B. (1958). The concealment of heavy bacterial contamination in 25 per cent. human serum albumin. Its mechanism and clinical significance. J. Lab. clin. Med. 51, 276.

Williams, R. E. O. (1954). Glucuronidase production by serotypes of Streptococcus pyogenes. J. gen. Microbiol. 10, 337.

Williams, R. E. O. (1958). Laboratory diagnosis of streptococcal infections. Bull. World Hlth Org. 19, 153. 